\title{
Incidence of keratoconus in spring catarrh
}

\author{
M DAUD KHAN, NIAMATULLAH KUNDI, NASIR SAEED, ARIFA GULAB, \\ AND ANISA F NAZEER \\ From the Lady Reading Hospital and Postgraduate Medical Institute, Peshawar, and the Khyber Hospital, \\ Peshawar, Pakistan
}

SUMMARY Five hundred and thirty cases of spring catarrh were studied at the Department of Ophthalmology, Khyber Hospital Peshawar, Pakistan. Corneal complications occurred in 259 patients, of which 48 cases were of keratoconus, consisting of 41 male and seven female patients. Most of the patients affected (37) were between the ages of 10 and 30 years. Six patients developed acute hydrops, which in one case affected both eyes, though after an interval of a few months. Keratoconus was progressive in many patients, resulting in gross visual loss, often not correctable with glasses or contact lenses and thus requiring keratoplasty. The importance of association of keratoconus with atopic disorders is discussed and its association with spring catarrh is stressed.

Keratoconus is a connective tissue disorder associated with bilateral thinning, scarring, and conical ectasia of axial or periaxial cornea accompanied by painless visual loss.' Although it may be associated with a number of local and systemic disorders, its exact pathogenesis is still not clear. ${ }^{2}$ The association of keratoconus with atopic conditions has been reported on many occasions. ${ }^{-2}$ Such clinical impressions have been substantiated by immunological disturbances such as significantly raised levels of total or specific IgE in serum." Hayfever, asthma, and eczema are reported to be usual atopic states associated with keratoconus..$^{2-1}$ Keratoconus is also known to be associated with spring catarrh, ${ }^{578}$ but such an association has been comparatively less frequently reported.

\section{Material and methods}

Five hundred and thirty cases of spring catarrh were studied at the Department of Ophthalmology, Khyber Hospital, Peshawar, from January 1982 to December 1984. Cases included were those that attended the hospital and one of the author's private clinic. The relevant details of history and clinical examination of the patients were recorded on a specially designed proforma. Examination included the usual methods of retinoscopy, ophthalmoscopy, and biomicroscopy. Patients with keratoconus were

Correspondence to M D Khan, Department of Ophthalmology. Postgraduate Medical Institute, Lady Reading Hospital, Peshawar. Pakistan. also examined with keratoscopes. Intraocular pressures were usually checked with Perkins' hand held applanation tonometer. The findings were analysed at the end of the period, and we report here our results on the incidence of keratoconus in the present series of patients with spring catarrh.

\section{Results}

Forty eight patients $(7 \%$ of the total number with spring catarrh) had keratoconus, of which 41 were male and seven female. The maximum number of patients occurred between the ages of 11 and 30 years (Table 1). No patients were below age 5 or over 35 . The peak frequency of patients affected was for those who had suffered with symptoms of spring catarrh for six to 10 years (Table 2).

The number of patients in this group who had other associated personal or familial allergies was 17; six had other personal allergies (all hayfever) and 11 had a family history of allergies (Table 3 ). $92 \%$ of patients had mixed lesions, as do most patients with spring catarrh in the region.

Topical steroids were the commonest medication used in this group $(92 \%)$, but one patient was taking only antihistaminics. The intraocular pressure appeared to be normal in all cases. Eight patients, seven male and one female, developed acute hydrops. One of them developed it in the second eye at an interval of a few months. Almost all settled down with conservative treatment, and many of them regained visual acuity of 6/18-6/24. 
Table 1 Age distribution of keratoconus among patients of spring catarrh

\begin{tabular}{lccc}
\hline Age in years & No. & $\%$ & Male:female \\
\hline $0-5$ & 0 & 0 & $-:-$ \\
$6-10$ & 5 & $10 \cdot 4$ & $3: 2$ \\
$11-15$ & 11 & $23 \cdot 0$ & $11: 0$ \\
$16-20$ & 17 & $35 \cdot 5$ & $14: 3$ \\
$21-25$ & 9 & $18 \cdot 7$ & $9: 0$ \\
$26-30$ & 4 & $8 \cdot 3$ & $4: 0$ \\
$31-35$ & 2 & $4 \cdot 1$ & $0: 2$ \\
Total & 48 & $100 \cdot 0$ & $41: 7$ \\
\hline
\end{tabular}

Table 2 Duration of spring catarrh

\begin{tabular}{llr}
\hline Duration in years & No. of patients & $\%$ \\
\hline $0-5$ & 13 & $27 \cdot 1$ \\
$6-10$ & 19 & $39 \cdot 6$ \\
$11-15$ & 15 & $31 \cdot 2$ \\
$16-20$ & 1 & $2 \cdot 1$ \\
over 20 & - & - \\
Total & 48 & $100 \cdot 0$ \\
\hline
\end{tabular}

Table 3 Allergies (familial and personal other than spring catarrh) among patients with keratoconus

\begin{tabular}{lrrc}
\hline Type of allergy & No. & $\%$ & Male:female \\
\hline Personal & 48 & $10(0 \cdot 0$ & $41: 7$ \\
Spring catarrh & 48 & $100 \cdot 0$ & $41: 7$ \\
Hayfever & 6 & $12 \cdot 5$ & $5: 1$ \\
Familial & 9 & $18 \cdot 8$ & $6: 3$ \\
Spring catarrh & 7 & $14 \cdot 6$ & $4: 3$ \\
Asthma and hayfever & 1 & $2 \cdot 1$ & $1: 0$ \\
Eczema & 1 & $2 \cdot 1$ & $1: 0$ \\
\hline
\end{tabular}

Table 4 Best correctable visual acuity in eyes with keratoconus

\begin{tabular}{llr}
\hline Visual status & No. of eyes & $\%$ \\
\hline HM-6/60 & 39 & $43 \cdot 8$ \\
$6 / 60-6 / 24$ & 20 & $22 \cdot 5$ \\
$6 / 18$ & 10 & $11 \cdot 5$ \\
$6 / 12$ & 13 & $14 \cdot 6$ \\
$6 / 9$ & 4 & $4 \cdot 5$ \\
$6 / 6($ after keratoplasty) & 3 & $3 \cdot 4$ \\
Total & 89 & $100 \cdot 0$ \\
\hline
\end{tabular}

Bilateral keratoconus occurred in the majority ( 41 cases); seven patients had only one eye involved, the other eye showing no signs of either keratoconus or high astigmatism. Of the 89 eyes affected with keratoconus 38 were legally blind, with a visual acuity of $6 / 60$ or less, while 20 eyes had marked visual handicap with a vision of more than $6 / 60$ but less than 6/24. After keratoplasty three eyes achieved corrected visual acuity of $6 / 6$ with glasses, while one eye achieved $6 / 18$ with glasses (Table 4 ).

Twenty six eyes showed early signs of keratoconus with corrected visual acuity (with glasses) ranging from $6 / 9$ to $6 / 18$. Owing to its high expense the facility of contact lenses could be extended to only a few individuals. Five patients had undergone keratoplasty, of whom three achieved corrected visual acuity of $6 / 6$, one $6 / 18$, and one had graft rejection twice. The facility of keratoplasty could also be offered to very few patients because of chronic shortage of donor material.

\section{Discussion}

Ridley first drew attention to the wide variety of atopic conditions associated with keratoconus." Copeman confirmed these findings." It was also Ridley who first noticed the prevalence of eye rubbing in keratoconus and reported it in $70 \%$ of his cases. " Karseras and Ruben confirmed this in 1976.' Since then an association between atopic states, eyerubbing and keratoconus has been reported by many workers." 1.3 These clinical findings have also been confirmed by noting biochemical changes in the form of a high incidence of raised total serum IgE and serum specific IgE in patients with keratoconus. $261+$

The usual atopic states reported to be commonly associated with keratoconus are hayfever, asthma, and eczema. ${ }^{--x}$ Its association with spring catarrh has also been noted and reported..$^{58}$ On the other hand not a single case was reported in two large studies on keratoconus. 212

In our study of 530 cases of spring catarrh we found a $7 \%$ incidence of keratoconus $(41$ male and 7 female), of which eight cases developed acute hydrops (seven male and one female). This is almost in agreement with the findings of Gormaz and Eggers, ${ }^{5}$ who noted an increased tendency to acute hydrops in their series; they also remarked on a significant male preponderance. We did not find any marked male preponderance, as there was a general male preponderance among patients with spring catarrh in a ratio of $5: 1$, while the ratio among patients with keratoconus and spring catarrh was $6: 1$. However, these findings are in disagreement with the marked female preponderance generally reported in patients of keratoconus. ${ }^{15}$ in

All patients of keratoconus in this study were suffering from spring catarrh, but besides this a number of other atopic conditions were found in the patients or their family members (Table 3). All patients had a normal intraocular pressure, and, though all of them received strong steroids at one time or another, none developed a subsequent marked rise of pressure. Raised pressure was, however, noted in patients with keratoconus by von Graefe in 1868, and chronic simple glaucoma was noted by d'Ermo in 1953 and Sbordone and de 
Simone in $1957 .{ }^{17}$

Keratoconus has been associated with a familial pattern of inheritance. Both dominant and recessive traits have been reported; consanguinity has also been blamed in some such cases. ${ }^{16}$ In our study we found only one case of spring catarrh with keratoconus, a patient who had a brother also suffering from spring catarrh with keratoconus; none of our other patients in this study gave any history of keratoconus among family members. This is a very small number considering that most marriages in our part of the world take place among near relatives, especially first cousins. We also did not note any other congenital anomalies among these patients in this study-for example, Down's syndrome or collagen disorders. This leaves us only with the theory of eye rubbing secondary to the intense irritation caused by the severe mixed type of spring catarrh that we see in the region.

This work was supported by the Pakistan Medical Research Council.

\section{References}

1 Bron AJ, Tripathi RC, Harding JJ, Crabbe MJC. Stromal loss in keratoconus. Trans Ophthalmol Soc UK 1978; 98: 393-6.

2 Rahi A, Davies P, Ruben M, Lobascher D, Menon J. Keratoconus and coexisting atopic disease. Br J Ophthalmol 1977; 61: 761-4.
3 Galin MA, Berger R. Atopy and keratoconus. Am J Ophthalmol 1958; 45: 904.

4 Spencer WA, Fisher JJ. The association of keratoconus with atopic dermatitis. Am J Ophthalmol 1959; 97: 332-4.

5 Gormaz A, Eggers C. Vernal keratoconjunctivitis and keratoconus. Am J Ophthalmol 1984; 96: 555-6.

$6 \mathrm{Kemp}$ EG, Lewis EJ. Immunoglobulin patterns in keratoconus with particular reference to total and specific $\operatorname{IgE}$ levels. $\mathrm{Br} J$ Ophthalmol 1982; 66: 717-20.

7 Bietti GB, Ferraboschi C. L'association du catarrhe printanier et du keratocone et son evidence statistique. Bull Mem Soc Fr Ophtalmol 1958; 71: 185-98.

8 Tabbara KP, Butrus SI. Vernal keratoconjunctivitis and keratoconus. Am J Ophthalmol 1983; 95: 704-5.

9 Ridley $\mathrm{H}$. Contact lenses in the treatment of keratoconus. $\mathrm{Br} \mathrm{J}$ Ophthalmol 1956; 40: 295-304.

10 Copeman PW. Eczema and keratoconus: $B r$ Med J 1965; ii: 977-9.

11 Ridley H. In: Contact lenses symposium. New York, Basle: Karger, 1966: 163-73.

12 Karseras AG, Ruben M. Aetiology of keratoconus. $\mathrm{Br} \mathrm{J}$ Ophthalmol 1976; 60: 522-5.

13 Coyle JJ. Keratoconus and eye rubbing. Am J Ophthalmol 1984; 97: $527-8$.

14 Easty DL, Entwhistle C, Funk A, Witcher J. Herpes simplex keratitis and keratoconus in atopic patients: a clinical and immunological study. Trans Ophthalmol Soc UK 1975; 95: 267-86.

15 Sorsby A, ed. Modern ophthalmology. 2nd ed. London: Butterworth, 1972: 3: chapter 1: 244.

16 Franschetti A. Keratoconus. In: King JH Jr, Metigne JW, eds. The cornea: World Congress. London: Butterworth, 1965: 157.

17 Duke-Elder S. System of ophthalmology. London: Kimpton, 1965: 8 (2): chapter 7: 964-76.

Accepted for publication 27 November 1986. 